\title{
Article \\ Differential Circulating MicroRNA Expression in Age-Related Macular Degeneration
}

\author{
Hanan ElShelmani ${ }^{1}$, Ian Brennan ${ }^{1,2}$, David J. Kelly ${ }^{3}$ and David Keegan ${ }^{1, *}$ \\ 1 Mater Misericordiae University Hospital, Eccles St., Dublin 7, Ireland; elshelh@tcd.ie (H.E.); \\ ibrennan@rcsi.ie (I.B.) \\ 2 University College Cork, College Road, Cork, Ireland \\ 3 Zoology Department, School of Natural Sciences, Trinity College Dublin, University of Dublin, \\ Dublin 2, Ireland; djkelly@tcd.ie \\ * Correspondence: dkeegan@mater.ie
}

Citation: ElShelmani, H.; Brennan, I.; Kelly, D.J.; Keegan, D. Differential Circulating MicroRNA Expression in Age-Related Macular Degeneration. Int. J. Mol. Sci. 2021, 22, 12321. https://doi.org/10.3390/ ijms222212321

Academic Editors: Janusz Blasiak and Kai Kaarniranta

Received: 30 September 2021 Accepted: 12 November 2021 Published: 15 November 2021

Publisher's Note: MDPI stays neutral with regard to jurisdictional claims in published maps and institutional affiliations.

Copyright: (c) 2021 by the authors. Licensee MDPI, Basel, Switzerland. This article is an open access article distributed under the terms and conditions of the Creative Commons Attribution (CC BY) license (https:/ / creativecommons.org/licenses/by/ $4.0 /)$.

\begin{abstract}
This study explored the expression of several miRNAs reported to be deregulated in age-related macular degeneration (AMD). Total RNA was isolated from sera from patients with dry $\operatorname{AMD}(n=12)$, wet AMD $(n=14)$, and controls $(n=10)$. Forty-two previously investigated miRNAs were selected based on published data and their role in AMD pathogenesis, such as angiogenic and inflammatory effects, and were co-analysed using a miRCURY LNA miRNA SYBR ${ }^{\circledR}$ Green PCR kit via quantitative real-time polymerase chain reaction (qRT-PCR) to validate their presence. Unsupervised hierarchical clustering indicated that AMD serum specimens have a different miRNA profile to healthy controls. We successfully validated the differentially regulated miRNAs in serum from AMD patients versus controls. Eight miRNAs (hsa-let-7a-5p, hsa-let-7d-5p, hsa-miR-23a-3p, hsa-miR-301a-3p, hsa-miR-361-5p, hsa-miR-27b-3p, hsa-miR-874-3p, hsa-miR-19b-1-5p) showed higher expression in the serum of dry AMD patients than wet AMD patients and compared with healthy controls. Increased quantities of certain miRNAs in the serum of AMD patients indicate that these miRNAs could potentially serve as diagnostic AMD biomarkers and might be used as future AMD treatment targets. The discovery of significant serum miRNA biomarkers in AMD patients would provide an easy screening tool for at-risk populations.
\end{abstract}

Keywords: microRNA; age-related macular degeneration; biomarkers; serum; dry AMD; wet AMD

\section{Introduction}

Age-related macular degeneration (AMD) is the most common cause of blindness in people over 60 years of age [1-3]. AMD is a progressive retinal disease that can broadly be categorised into either "dry" atrophic AMD or "wet" neovascular AMD. Atrophic AMD is characterised in its early stages by dysfunction of the retinal pigment epithelium (RPE) along with the formation of drusen in Bruch's membrane [4,5]. These changes result in atrophy and damage to the photoreceptor cells and RPE which in turn results in a slow, progressive, and irreversible loss of vision [4,5]. Geographic atrophy of the retina with corresponding significant visual deficit is seen in late-stage atrophic AMD [2,6]. Neovascular AMD is another form of late-stage disease, where loss of vision is attributable to the formation of new vessels within and below the retina via choroidal neovascularisation $[2,6,7]$. These new vessels are disorganised, friable and prone to haemorrhage, aberrant fibrovascular scarring and detachment, and RPE [1,2,5,7]. As a result, the progression of visual loss is markedly more rapid in neovascular AMD compared to atrophic AMD [2,6,8].

AMD has an insidious clinical onset, and as yet there are no effective means of screening for the disease $[9,10]$. Moreover, fundoscopy, imaging and self-monitoring for disease progression fall short of identifying patients who will go on to develop neovascular disease [9]. Therefore, there is a distinct need for the identification of useful AMD biomarkers that could be used in the diagnosis and recognition of disease progression. 
MicroRNAs (miRNAs) are small noncoding RNA molecules involved in post-translational regulation of gene expression through the targeting and silencing of complementary messenger RNA (mRNA) $[1,10,11]$. Gene silencing by miRNA is thought to play a role in controlling a variety of both physiological and pathological processes [12]. It has also been shown that miRNA expression changes with ageing, and miRNAs that are normally downregulated by ageing remain unusually normal or become elevated in patients with AMD $[10,13]$.

Indeed, miRNAs have been shown to have a governing function in processes underpinning AMD, such as inflammation, angiogenesis, and oxidative stress responses [12,14,15]. Additionally, AMD is a neurodegenerative disease [16] and there is interest in the commonality of some miRNAs expressed in AMD and in other neurodegenerative diseases, such as Alzheimer's disease $[4,15,17]$. Their distinctive expression in these disease-states and their relative stability in serum samples make miRNAs very promising diagnostic biomarkers, and potential therapeutic targets $[4,9,18-20]$.

Numerous clinical studies have investigated the differential expression of miRNAs in the serum of patients with AMD (Table 1). This study aims to validate a number of promising serum miRNA biomarkers identified in AMD, and to characterise their expression in the context of Irish patients with AMD.

Table 1. miRNAs identified in the literature as being differentially expressed in AMD patients compared with healthy controls or implicated in AMD pathogenesis. All sample tissues are human, unless otherwise stated. PBNCs = Peripheral blood nucleated cells.

\begin{tabular}{|c|c|c|c|c|}
\hline miRNA & Sample Type & AMD Type & $\begin{array}{c}\text { Proposed Role in AMD } \\
\text { Pathogenesis }\end{array}$ & Reference \\
\hline miR-374a & $\begin{array}{l}\text { Serum [10] } \\
\text { Plasma [21] }\end{array}$ & Dry & $\begin{array}{c}\text { Oxidative stress } \\
\text { response [22] } \\
\text { Neurodegeneration [22] }\end{array}$ & $\begin{array}{l}\text { ElShelmani et al., } 2020 \text { [10] } \\
\text { Ertekin et al., } 2014 \text { [21] }\end{array}$ \\
\hline miR-19a & Serum [10] & Dry & $\begin{array}{c}\text { Cell growth [10] } \\
\text { Apoptosis [10] } \\
\text { Angiogenesis [10] }\end{array}$ & ElShelmani et al., 2020 [10] \\
\hline miR-296-5p & Serum [10] & Dry & $\begin{array}{l}\text { Oxidative stress } \\
\text { response [23] }\end{array}$ & ElShelmani et al., 2020 [10] \\
\hline $\operatorname{miR}-19 b$ & Serum [10] & Dry & $\begin{array}{c}\text { Cell growth [10] } \\
\text { Apoptosis [10] } \\
\text { Angiogenesis [10] }\end{array}$ & ElShelmani et al., 2020 [10] \\
\hline miR-126 & $\begin{array}{l}\text { Serum }[4,10] \\
\text { PBNCs }[14]\end{array}$ & Dry + Wet & $\begin{array}{l}\text { Inflammation }[5,10] \\
\text { Angiogenesis }[5,10] \\
\text { Apoptosis }[10]\end{array}$ & $\begin{array}{l}\text { ElShelmani et al., } 2020 \text { [10] } \\
\text { Litwińska et al., } 2019 \text { [14] } \\
\text { Romano et al., } 2017 \text { [4] }\end{array}$ \\
\hline $\operatorname{miR}-16$ & $\begin{array}{l}\text { Plasma [24] } \\
\text { PBNCs [14] }\end{array}$ & Dry + Wet & $\begin{array}{c}\text { Apoptosis [24] } \\
\text { Cell growth [24] } \\
\text { Inflammation }[14,24]\end{array}$ & $\begin{array}{l}\text { Litwińska et al., } 2019 \text { [14] } \\
\text { Ulańczyk et al., } 2019 \text { [24] }\end{array}$ \\
\hline $\operatorname{miR}-486-5 p$ & $\begin{array}{l}\text { Serum [10] } \\
\text { Serum exosomes [8] }\end{array}$ & Dry + Wet & $\begin{array}{l}\text { Angiogenesis [8] } \\
\text { Inflammation [8] } \\
\text { Cell growth [8] } \\
\text { Apoptosis [8] }\end{array}$ & $\begin{array}{l}\text { ElShelmani et al., } 2020 \text { [10] } \\
\text { Elbay et al., } 2019 \text { [8] }\end{array}$ \\
\hline hsa-miR-155 & $\begin{array}{c}\text { Serum [4] } \\
\text { Plasma [21,24] } \\
\text { PBNCs [14] } \\
\text { Retina [25] }\end{array}$ & Dry + Wet & $\begin{array}{c}\text { Inflammation [4-6] } \\
\text { Angiogenesis [5,6] } \\
\text { Apoptosis [4] }\end{array}$ & $\begin{array}{c}\text { Litwińska et al., } 2019 \text { [14] } \\
\text { Ulańczyk et al., } 2019 \text { [24] } \\
\text { Romano et al., } 2017 \text { [4] } \\
\text { Ertekin et al., } 2017 \text { [21] } \\
\text { Pogue et al., } 2018 \text { [25] }\end{array}$ \\
\hline hsa-miR-626 & Serum exosomes [8] & Dry + Wet & Neurodegeneration [8] & Elbay et al., 2019 [8] \\
\hline
\end{tabular}


Table 1. Cont.

\begin{tabular}{|c|c|c|c|c|}
\hline miRNA & Sample Type & AMD Type & $\begin{array}{c}\text { Proposed Role in AMD } \\
\text { Pathogenesis }\end{array}$ & Reference \\
\hline hsa-miR-9 & Serum [4] & Dry + Wet & $\begin{array}{l}\text { Inflammation [5] } \\
\text { Oxidative stress } \\
\text { response [5] }\end{array}$ & Romano et al., 2017 [4] \\
\hline hsa-miR-23a & $\begin{array}{c}\text { Serum [4] } \\
\text { Plasma [24] } \\
\text { PBNCs [14] } \\
\text { Mouse retinal tissue [26] }\end{array}$ & Dry + Wet & $\begin{array}{l}\text { Oxidative stress } \\
\text { response [5] } \\
\text { Angiogenesis [5] }\end{array}$ & $\begin{array}{c}\text { Litwińska et al., } 2019 \text { [14] } \\
\text { Ulańczyk et al., } 2019 \text { [24] } \\
\text { Romano et al., } 2017 \text { [4] } \\
\text { Zhou et al., 2011 [24] }\end{array}$ \\
\hline hsa-miR-34a & $\begin{array}{c}\text { Serum [4] } \\
\text { In vitro retinal pigment } \\
\text { epithelium [27] } \\
\text { Mouse retinal tissue [28] }\end{array}$ & Dry + Wet & $\begin{array}{c}\text { Oxidative stress } \\
\text { response [5] } \\
\text { Cell growth [27] } \\
\text { Cell proliferation [27] }\end{array}$ & $\begin{array}{c}\text { Romano et al., } 2017 \text { [4] } \\
\text { Smit-McBride et al., } \\
2014 \text { [28] } \\
\text { Hou et al., 2013 [27] }\end{array}$ \\
\hline $\operatorname{miR}-874$ & Serum [10] & Wet & Neurodegeneration [29] & ElShelmani et al., 2020 [10] \\
\hline $\operatorname{miR}-132$ & $\begin{array}{c}\text { Serum [10] } \\
\text { Serum exosomes [8] }\end{array}$ & Wet & $\begin{array}{c}\text { Angiogenesis [5,8] } \\
\text { Cell proliferation [8] } \\
\text { Angiogenesis [8] }\end{array}$ & $\begin{array}{l}\text { ElShelmani et al., } 2020 \text { [10] } \\
\text { Elbay et al., 2019 [8] }\end{array}$ \\
\hline $\mathrm{miR}-27 \mathrm{~b}$ & $\begin{array}{l}\text { Serum [10] } \\
\text { Plasma [21] }\end{array}$ & Wet & Angiogenesis $[5,21]$ & $\begin{array}{c}\text { ElShelmani et al., } 2020 \text { [10] } \\
\text { Ertekin et al., 2014 [21] }\end{array}$ \\
\hline $\operatorname{miR}-25$ & $\begin{array}{c}\text { Serum [10] } \\
\text { Plasma [21] } \\
\text { Whole blood [9] } \\
\text { Rat retinal tissue [30] }\end{array}$ & Wet & $\begin{array}{c}\text { Oxidative stress response } \\
{[30]}\end{array}$ & $\begin{array}{c}\text { ElShelmani et al., } 2020 \text { [10] } \\
\text { Ren et al., 2017 [9] } \\
\text { Zhang et al., 2017 [30] } \\
\text { Ertekin et al., 2014 [21] }\end{array}$ \\
\hline $\operatorname{miR}-146 a$ & $\begin{array}{c}\text { Serum }[4,10] \\
\text { Plasma [18] } \\
\text { PBNCs [14] } \\
\text { Vitreous humour [31] } \\
\text { Retina [25] }\end{array}$ & Wet & $\begin{array}{c}\text { Inflammation [4-6] } \\
\text { Oxidative stress response } \\
{[6]} \\
\text { Neurodegeneration [6] } \\
\text { Angiogenesis [6] }\end{array}$ & $\begin{array}{c}\text { ElShelmani et al., } 2020 \text { [10] } \\
\text { Litwińska et al., } 2019 \text { [14] } \\
\text { Ulańczyk et al., } 2019 \text { [24] } \\
\text { Romano et al., } 2017 \text { [4] } \\
\text { Ménard et al., } 2016 \text { [31] } \\
\text { Pogue et al., } 2018 \text { [25] }\end{array}$ \\
\hline $\operatorname{miR}-410$ & $\begin{array}{l}\text { Serum [10] } \\
\text { Plasma [21] }\end{array}$ & Wet & Inflammation [10] & $\begin{array}{c}\text { ElShelmani et al., } 2020 \text { [10] } \\
\text { Ertekin et al., } 2014 \text { [21] }\end{array}$ \\
\hline hsa-miR-125b & $\begin{array}{c}\text { Retinoblastoma cell lines } \\
\text { [32] } \\
\text { Retina [25] }\end{array}$ & Wet & $\begin{array}{l}\text { Inflammation [5] } \\
\text { Angiogenesis [6] }\end{array}$ & $\begin{array}{l}\text { Pogue et al., } 2018 \text { [25] } \\
\text { Bai et al., } 2016 \text { [32] }\end{array}$ \\
\hline hsa-miR-27a & $\begin{array}{c}\text { Whole blood [9] } \\
\text { Serum [4] } \\
\text { Mouse retinal tissue [26] }\end{array}$ & Wet & $\begin{array}{c}\text { Angiogenesis [5] } \\
\text { Neurodegeneration [4] } \\
\text { Inflammation [4] }\end{array}$ & $\begin{array}{c}\text { Ren et al., } 2017 \text { [9] } \\
\text { Romano et al., } 2017 \text { [4] } \\
\text { Zhou et al., } 2011 \text { [26] }\end{array}$ \\
\hline hsa-miR-93 & $\begin{array}{l}\text { Mouse retinal tissue [1] } \\
\text { Plasma [24] }\end{array}$ & Wet & Angiogenesis $[1,5,24]$ & $\begin{array}{l}\text { Wang et al., } 2016 \text { [4] } \\
\text { Ulańczyk et al., } 2019 \text { [24] }\end{array}$ \\
\hline hsa-miR-301-3p & Serum [2] & Wet & Angiogenesis [2] & Grassmann et al., 2014 [2] \\
\hline hsa-miR-361-5p & Serum [2] & Wet & Angiogenesis [2] & Grassmann et al., 2014 [2] \\
\hline hsa-miR-424-5p & Serum $[2,11]$ & Wet & Angiogenesis [2] & $\begin{array}{l}\text { Grassmann et al., } 2014 \text { [2] } \\
\text { Szemraj et al., } 2015 \text { [11] }\end{array}$ \\
\hline hsa-let-7a-5p & Serum [11] & Wet & Angiogenesis [11] & Szemraj et al., 2015 [11] \\
\hline hsa-let-7d-5p & Serum [11] & Wet & Angiogenesis [11] & Szemraj et al., 2015 [11] \\
\hline hsa-let-7b-5p & Serum [11] & Wet & Angiogenesis [11] & Szemraj et al., 2015 [11] \\
\hline $\mathrm{miR}-200 \mathrm{~b}$ & $\begin{array}{l}\text { Mouse retinal tissue [33] } \\
\text { Rat retinal tissue [34] }\end{array}$ & Wet & $\begin{array}{c}\text { Oxidative stress response } \\
{[33,34]} \\
\text { Angiogenesis [34] }\end{array}$ & $\begin{array}{l}\text { Murray et al., } 2013 \text { [33] } \\
\text { McArthur et al., } 2011 \text { [34] }\end{array}$ \\
\hline
\end{tabular}


Table 1. Cont.

\begin{tabular}{ccccc}
\hline miRNA & Sample Type & AMD Type & $\begin{array}{c}\text { Proposed Role in AMD } \\
\text { Pathogenesis }\end{array}$ & Reference \\
\hline miR-205-5p & $\begin{array}{c}\text { Serum [7] } \\
\text { In vitro retinal pigment } \\
\text { epithelium [35] }\end{array}$ & Wet & Oxidative stress response & Oltra et al., 2020 [35] \\
[35] & Angiogenesis [7,35] & Blasiak et al., 2019 [7] \\
\hline
\end{tabular}

Mature miRNAs are derived from the $3^{\prime}$ and $5^{\prime}$ ends of the same precursor. The pre-miRNA hairpin is cleaved by the RNase III enzyme Dicer to create mature miRNA from the two arms of the duplex. These mature miRNAs have two nucleotides overhanging on their $3^{\prime} / 5^{\prime}$ ends (miRNA-3p and miRNA-5p, respectively). It is known that, in some cases, both miRNA-5p and miRNA-3p are functional and target different RNA populations [36-38], though the selection of $3 p / 5 p$ arm preference remains unclear [38]. This may account for some of the dual effects noticed in a number of studies under different biological conditions [14,24]. For example, miR-410 was discovered by ElShelmani et al. and Ertekin et al. to be dysregulated in AMD patients. It has two mature forms: miR-410-3p (sequence: AAUAUAACACAGAUGGCCUGU) and miR-410-5p (sequence: AGGUUGUCUGUGAUGAGUUCG) $[10,21,39,40]$.

The objective of this study was to explore the expression of several miRNAs reported to be deregulated in AMD. Such differentially expressed serum miRNA could be used as AMD biomarkers. Furthermore, our study focused on finding the exact mature form of miRNAs that are overexpressed in the serum of AMD patients. Having selected relevant miRNAs from the literature, we were able to utilise miRbase (http:/ / www.mirbase.org/, accessed on 1 February 2021) to find the mature form of each miRNA selected in this project $[39,40]$.

\section{Results}

2.1. AMD miRNA Biomarkers, Data Quality Control, and Normalisation

The steady levels of the assay shown in Figure 1 indicate that both reverse transcription and qRT-PCR were successful. RNA spike-in control UniSp6 expression level indicates that the reverse transcription was also successful. UniSp3 indicates good technical performance of the qPCR (Figure 1).

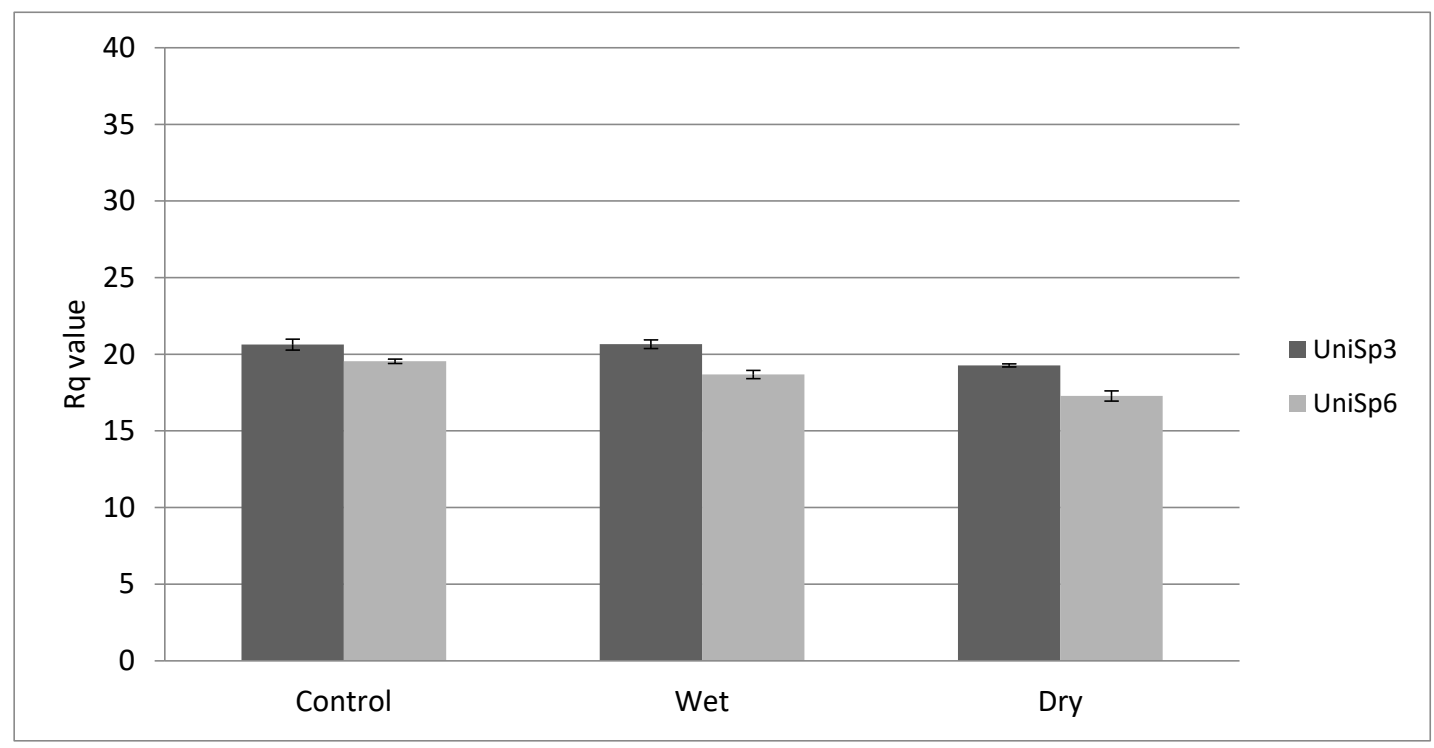

Figure 1. Raw $\mathrm{Rq}$ value (mean $\pm \mathrm{SD}$ ) obtained for the RNA spike-in assay. The steady level of the assays indicates that both RT and qRT-PCR were successful $(n=36)$. Dry = atrophic AMD, Wet = neovascular AMD. 
miR-451a and miR-23a-3p are relatively stable in serum and plasma and are not affected by haemolysis. $\Delta \mathrm{Rq}(\mathrm{miR}-23 \mathrm{a}, \mathrm{miR}-451 \mathrm{a})$ lower than 5 in human serum or plasma represents non-haemolyzed samples. If the $\Delta \mathrm{Rq}$ is close to or higher than 7 , there is an increased risk of haemolysis. In this study, any samples that showed $\Delta \mathrm{Rq}$ higher than 7 were excluded (Figure S1). The $\Delta \mathrm{Rq}$ for UniSp2, UniSp4, UniSp5 RNA Spike-in were 2-3 Rq difference within a dataset. Any sample showed higher differences of $\Delta \mathrm{Rq}$ were excluded from the study (Figure S1).

Normalisation was performed based on the average of three miRNAs detected in all specimens (miR-324-3p, miR-423-3p and miR-423-5p) (Figure 2). miR-323-3p was excluded from the normalization as it showed higher values than the three other endogenous controls (Figure 2).

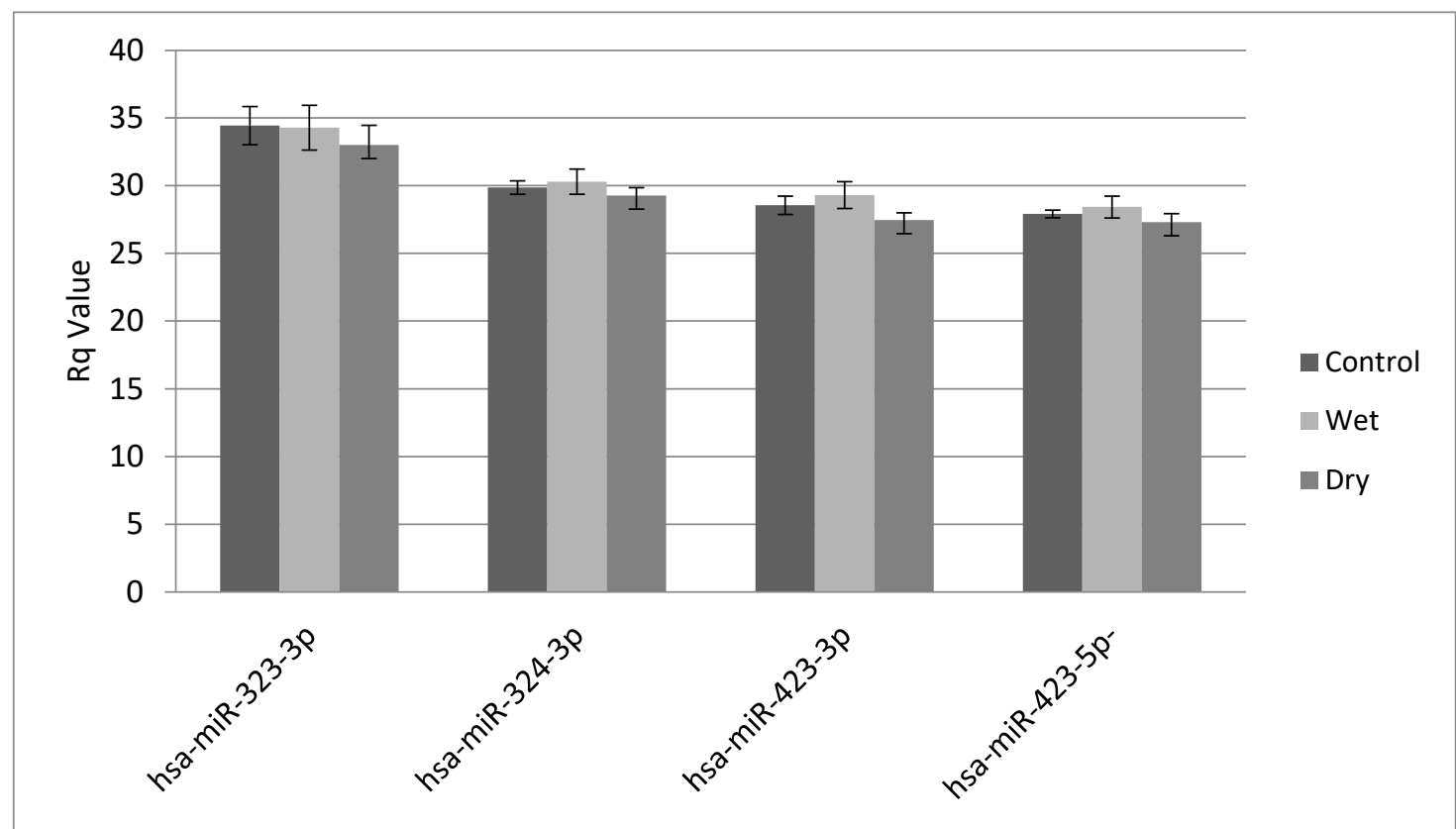

Figure 2. Raw Rq obtained for the four control miRNA assays used for normalisation (ANOVA: $p=0.132$ ). Dry $=$ atrophic AMD, Wet $=$ neovascular AMD. miR-324-3p $(p=0.172)$, miR-423-3p $(p=0.201)$, and miR423-5p $(p=0.168)$ were used for normalization in this study.

\subsection{Differentially Expressed miRNAs in AMD}

Hierarchical clustering analysis (Figure 3) performed for the study, using Morpheus software (https:/ / clue.io/morpheus, accessed on 1 April 2021), showed the differential expressions of the miRNA candidates in wet and dry AMD patients groups compared with controls. Red and green colours indicate high- and low-expression intensities. Table 2 shows the individual results for these miRNAs.

Table 2. miRNA names, $p$-values from ANOVA of dry, wet and control samples, and post-hoc tests comparing dry vs. control and wet vs. control samples. $p$-values: ${ }^{*} \leq 0.05,{ }^{* *} \leq 0.01,{ }^{* * *} \leq 0.001$.

\begin{tabular}{ccccc}
\hline \multirow{2}{*}{ miRNA } & ANOVA $p$-Value & $\begin{array}{c}p \text {-Value Adjusted for } \\
\text { Multiple Tests }\end{array}$ & \multicolumn{2}{c}{ Post-Hoc Test } \\
\cline { 4 - 5 } & & $0.0000915^{* * *}$ & Dry vs. Control & Wet vs. Control \\
\hline let-7a-5p & $0.0000023^{* * *}$ & $0.0011159^{* *}$ & $0.000000102^{* * *}$ & $5.04 \mathrm{E}-04^{* * *}$ \\
\hline let-7b-5p & $0.0000338^{* * *}$ & $0.0000084^{* * *}$ & $5.42 \mathrm{E}-09^{* * *}$ & $3.30 \mathrm{E}-04^{* * *}$ \\
\hline let-7d-5p & $0.0000002^{* * *}$ & 0.0536036 & $0.001766642^{* * *}$ & $0.000150437^{* * *}$ \\
\hline miR-125b-5p & $0.0041234^{* *}$ &
\end{tabular}


Table 2. Cont.

\begin{tabular}{|c|c|c|c|c|}
\hline \multirow{2}{*}{ miRNA } & \multirow{2}{*}{ ANOVA $p$-Value } & \multirow{2}{*}{$\begin{array}{l}p \text {-Value Adjusted for } \\
\text { Multiple Tests }\end{array}$} & \multicolumn{2}{|c|}{ Post-Hoc Test } \\
\hline & & & Dry vs. Control & Wet vs. Control \\
\hline miR-155-5p & $0.0002756^{* * *}$ & $0.0064747^{* *}$ & $0.000000316^{* * *}$ & $7.85 \mathrm{E}-04^{* * *}$ \\
\hline miR-23a-3p & $0.0000055^{* * *}$ & $0.0002102 * * *$ & $8.03 \mathrm{E}-08^{* * *}$ & $1.12 \mathrm{E}-02 *$ \\
\hline miR-27a-3p & $0.0000339^{* * *}$ & $0.0011159 * *$ & 3.67E-09 *** & $1.53 \mathrm{E}-04^{* * *}$ \\
\hline miR-301a-3p & $0.0000173^{* * *}$ & $0.0006216^{* * *}$ & $0.000000121^{* * *}$ & $1.74 \mathrm{E}-03^{* *}$ \\
\hline miR-34a-3p & $0.0029547^{* *}$ & 0.0472756 * & $0.001283794^{* *}$ & $0.001283794 * *$ \\
\hline miR-361-5p & $0.0000003^{* * *}$ & $0.000013^{* * *}$ & 2.93E-09 *** & $1.27 \mathrm{E}-04^{* * *}$ \\
\hline $\operatorname{miR}-424-5 p$ & 0.0134416 * & 0.0997292 & $0.000240525 * * *$ & $0.002441783 * *$ \\
\hline miR-626 & 0.0282197 * & 0.1128788 & 1 & $0.0241612 *$ \\
\hline miR-9-5p & $0.0124661^{*}$ & 0.0997292 & 0.005665279 ** & 0.078181678 \\
\hline $\operatorname{miR}-93-5 p$ & $0.0000965^{* * *}$ & $0.0027007^{* *}$ & $0.00000149^{* * *}$ & $7.59 \mathrm{E}-04^{* * *}$ \\
\hline $\operatorname{miR}-126-3 p$ & $0.0000879^{* * *}$ & $0.0026358^{* *}$ & $8.65 \mathrm{E}-08^{* * *}$ & $1.22 \mathrm{E}-03^{* *}$ \\
\hline $\operatorname{miR}-132-3 p$ & $0.0000976^{* * *}$ & $0.0027007^{* *}$ & $0.00000751^{* * *}$ & $1.62 \mathrm{E}-04^{* * *}$ \\
\hline miR-146a-5p & $0.0000308^{* * *}$ & $0.0010487^{* *}$ & $0.000000118^{* * *}$ & $5.47 \mathrm{E}-03 * *$ \\
\hline miR-16-1-3p & $0.006405^{* *}$ & 0.0659499 & $0.000417055^{* * *}$ & $0.004765244^{* *}$ \\
\hline miR-19a-3p & $0.0009344^{* * *}$ & 0.0177531 * & $0.000000344^{* * *}$ & $1.14 \mathrm{E}-04^{* * *}$ \\
\hline $\operatorname{miR}-19 b-3 p$ & $0.0000817^{* * *}$ & $0.0025317^{* *}$ & $7.75 \mathrm{E}-08^{* * *}$ & $2.72 \mathrm{E}-04^{* * *}$ \\
\hline $\operatorname{miR}-25-3 p$ & $0.0003701^{* * *}$ & $0.0077725^{* *}$ & $0.0000263^{* * *}$ & $1.04 \mathrm{E}-02 *$ \\
\hline $\operatorname{miR}-27 b-3 p$ & $0.0000016^{* * *}$ & $0.0000658^{* * *}$ & $2.46 \mathrm{E}-08^{* * *}$ & $1.00 \mathrm{E}-02 *$ \\
\hline $\operatorname{miR}-296-5 p$ & $0.0000902^{* * *}$ & $0.0026358^{* *}$ & $0.00000361^{* * *}$ & $1.42 \mathrm{E}-04^{* * *}$ \\
\hline miR-374a-3p & $0.0002002^{* * *}$ & $0.0052054^{* *}$ & $0.0000189^{* * *}$ & $2.24 \mathrm{E}-02 *$ \\
\hline $\operatorname{miR}-410-3 p$ & $0.0002989^{* * *}$ & $0.0065768^{* *}$ & $0.00000215^{* * *}$ & $3.08 \mathrm{E}-02 *$ \\
\hline miR-486-5p & $0.0026621^{* *}$ & $0.0452558 *$ & $0.000196392^{* * *}$ & 0.012940657 * \\
\hline miR-874-3p & $0.0000208^{* * *}$ & $0.0007281^{* * *}$ & $0.000000903^{* * *}$ & $7.41 \mathrm{E}-05^{* * *}$ \\
\hline miR-200b-3p & $0.0059954^{* *}$ & 0.0659499 & $0.000513111^{* * *}$ & 0.048144232 * \\
\hline hsa-miR-205-5p & 0.4166033 & 0.8332066 & $0.01844464 *$ & 0.04330408 * \\
\hline $\operatorname{miR}-23 a-5 p$ & 0.017179 * & 0.1030738 & $0.002440702 * *$ & $0.002440702 * *$ \\
\hline $\operatorname{miR}-27 a-5 p$ & $0.0094173^{* *}$ & 0.0847555 & $0.001859376^{* *}$ & $0.019768118 *$ \\
\hline miR-34a-5p & $0.0002132^{* * *}$ & $0.0053307^{* *}$ & $0.0000367^{* * *}$ & $3.67 \mathrm{E}-05^{* * *}$ \\
\hline $\operatorname{miR}-126-5 p$ & $0.0002698^{* * *}$ & $0.0064747^{* *}$ & $0.00000375^{* * *}$ & $6.31 \mathrm{E}-04^{* * *}$ \\
\hline miR-132-5p & 0.0839077 & 0.251723 & 0.09591552 & 0.43207043 \\
\hline $\operatorname{miR}-16-5 p$ & $0.0029939 * *$ & $0.0472756^{*}$ & $0.00000267^{* * *}$ & $1.69 \mathrm{E}-04^{* * *}$ \\
\hline $\operatorname{miR}-19 a-5 p$ & $0.0047982 * *$ & 0.0575782 & $0.0000288^{* * *}$ & $2.44 \mathrm{E}-03 * *$ \\
\hline $\operatorname{miR}-25-5 p$ & $0.0215507^{*}$ & 0.1077534 & $0.004209305^{* *}$ & $0.042136988 *$ \\
\hline $\operatorname{miR}-27 b-5 p$ & $0.0030667^{* *}$ & $0.0472756^{*}$ & $0.002349743^{* *}$ & 0.113657163 \\
\hline miR-374a-5p & $0.0007715^{* * *}$ & $0.01543 *$ & $0.000000704^{* * *}$ & $4.05 \mathrm{E}-03 * *$ \\
\hline $\operatorname{miR}-410-5 p$ & 0.4354663 & 0.8332066 & 0.9400418 & 0.5086931 \\
\hline miR-874-5p & 0.0011751 ** & $0.0211526^{*}$ & $0.000117408^{* * *}$ & $0.028667993 *$ \\
\hline miR-19b-1-5p & $0.0000068^{* * *}$ & $0.0002523^{* * *}$ & $0.00000196^{* * *}$ & $9.66 \mathrm{E}-02$ \\
\hline
\end{tabular}




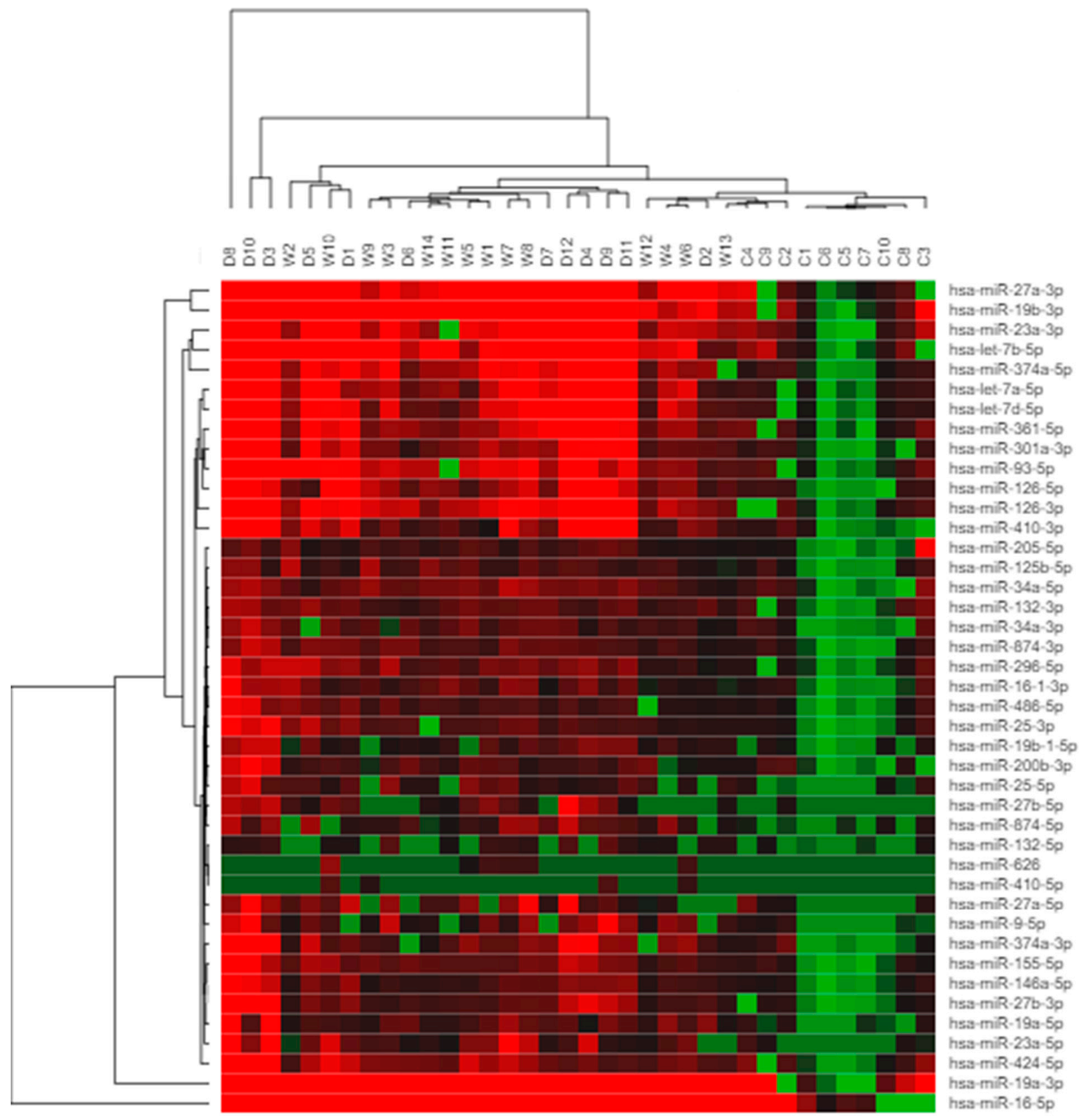

Figure 3. Hierarchical clustering of differentially regulated miRNAs. The clustering map represents miRNA differential expression in AMD patients and controls. Each row represents one miRNA, and each column represents one sample (dry, wet and control). Red = expression level above the mean, green = expression lower than the mean, $(\mathrm{D} 1, \mathrm{D} 2, \ldots, \mathrm{D} 12=\mathrm{dry}$ AMD specimens; W1, W2, ..., W14 = wet AMD specimens; $\mathrm{C} 1, \mathrm{C} 2, \ldots, \mathrm{C} 10$ = control).

\subsection{MicroRNAs as Candidate Biomarkers for AMD}

Thirty-nine up-regulated miRNAs (Table 2, Figure 3) were confirmed to be overexpressed in the serum of AMD patients. Post-hoc pairwise comparisons were made of the dry vs. control samples and wet vs. control samples. Eight miRNAs (hsa-let-7a-5p, hsa-let-7d-5p, hsa-miR-23a-3p, hsa-miR-301a-3p, hsa-miR-361-5p, hsa-miR-27b-3p, hsamiR-874-3p, and hsa-miR-19b-1-5p) showed higher expression in the serum of dry AMD 
patients compared with healthy controls than in wet AMD patients compared with healthy controls.

\section{Discussion}

Our study successfully profiled the differential quantities of miRNAs in serum from AMD patients compared with healthy controls in an Irish context. Markedly different miRNA expression profiles were identified between the two groups. Of the candidate miRNAs selected for examination, 39 were significantly up-regulated in the serum of AMD patients compared with controls, validating their usefulness as potential biomarkers for AMD in Irish patients (Table 2, Figure 4). On MDS analysis of RQ values for each of miRNA, patients with both 'dry' and 'wet' AMD exhibited consistently raised expression levels of candidate miRNAs (Figure 5). Additionally, patients with AMD appear to cluster together, underlining the relative closeness in fold change of miRNA expression in these patients. Controls on the other hand, can be seen to be dispersed. Moreover, eight miRNAs identified showed higher expression in the serum of dry AMD patients than in that of wet AMD patients compared with healthy controls: hsa-let-7a-5p, hsa-let-7d-5p, hsa-miR-19b-1-5p, hsa-miR-23a-3p, hsa-miR-27b-3p, hsa-miR-301a-3p, hsa-miR-361-5p, and hsa-miR-874-3p. The differences between patients with dry AMD and wet AMD lends promise to the potential prognostic value of miRNA biomarkers.

The miRNAs identified in this study have been previously shown to play important roles in the regulation of AMD pathogenesis. Let-7 family of miRNAs, for example, was shown to respond to oxidative stress induced by hypoxic conditions in vitro, modelling conditions observed in AMD [11,41]. Let-7 miRNAs are highly expressed in retinal tissues and vascular endothelial cells [5,41]. Szemraj et al., 2015, proposed that Let-7 miRNAs promote pro-angiogenic processes in patients with wet $\mathrm{AMD}$ in response to these hypoxic conditions [11]. miR-27b also promotes angiogenesis via its regulation of Sprouty2 and semaphorin $6 \mathrm{~A}$ target proteins. It is via these pathways that miR-27b has been implicated in the control of vascular endothelial sprouting in angiogenesis [21]. Ertekin et al. hypothesised that miR-27b acts as an early indicator of an angiogenic switch in AMD [21].

Grassmann et al., 2014, identified novel biomarkers for late-stage wet AMD through next-generation sequencing of circulating miRNAs in plasma from wet AMD patients [2]. Circulating miRNAs of 203 in number were identified, with miR-301a-3p, miR-361 expression notably shown to be significantly altered in patients compared with AMD-free controls [2]. Their role in cellular responses to ischaemic stress and damage was highlighted in this study, which implicated them in the control of TGF- and mTOR signalling pathways. [2]. Aberrant expression of miR-23a is also known to regulate gene expression in ischaemic conditions [42]. miR-23a was shown to regulate Fas expression in ARPE-19 cells, thereby promoting cell survival in the setting of oxidative stress [42]. Similarly, miR-874-3p has been shown to protect stroke patients from ischemic neuronal injury by inhibiting the pro-apoptotic factors BMF and BCL2L13 [43].

AMD has been shown to be associated with neurodegeneration, and many of the miRNAs identified in this study have been shown to have a role in neurodegenerative processes. Taking hsa-Let-7d-5p, this miRNA was suggested as a potential biomarker for Alzheimer's disease [44]. This is particularly noteworthy given the link between AMD and Alzheimer's [4,15] In addition to this, Shahriari et al. (2020) found that MITF expression in RPE cells was influenced by hsa-let-7a-5p, promoting RPE differentiation at the expense of neural differentiation [45]. miR-874-5p has also been implicated in influencing gene expression in in vitro neurodegenerative disease models. It has been associated with the promotion of neuronal damage in Parkinson's disease (MPP+-triggered neuronal damage in SK-N-SH cells) via the miR-874-5p/ATG10 axis [46]. 
Volcano plot for dry AMD data

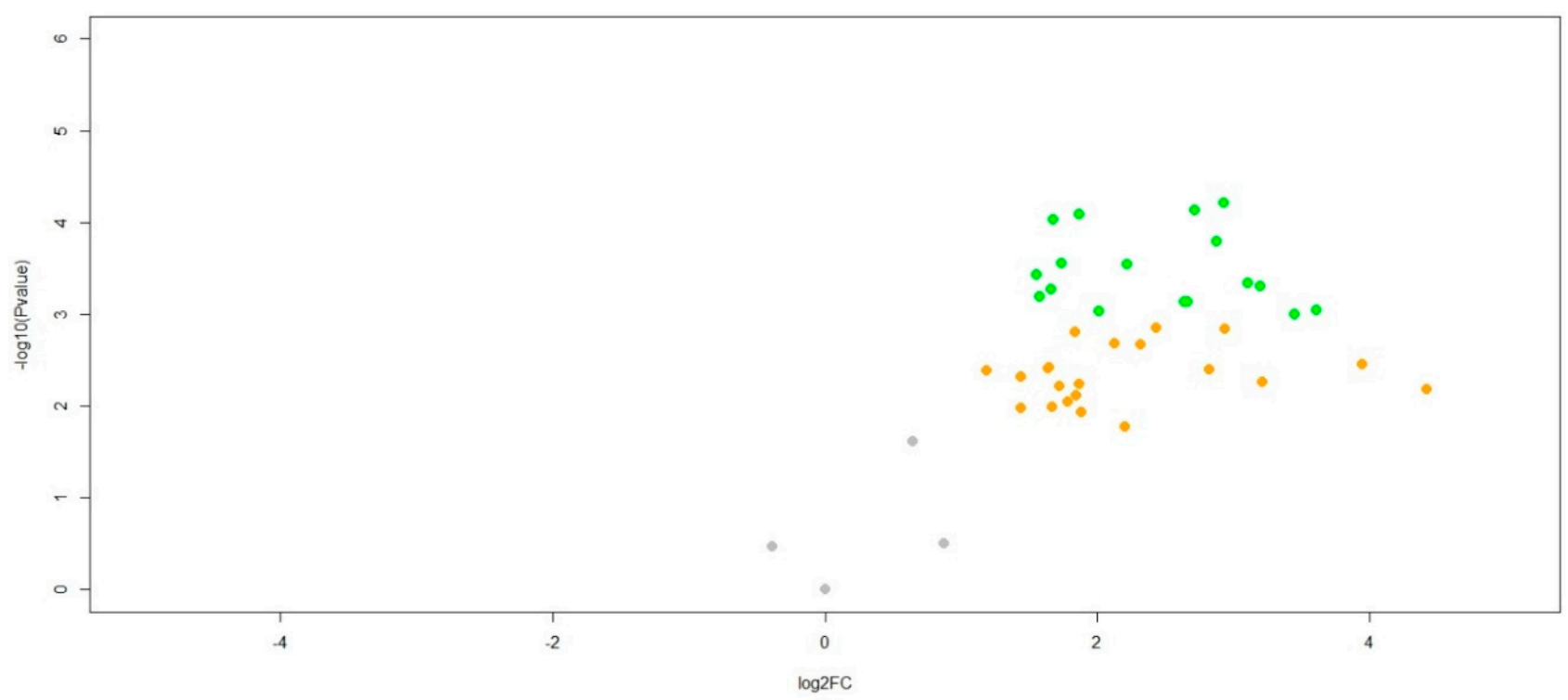

(a)

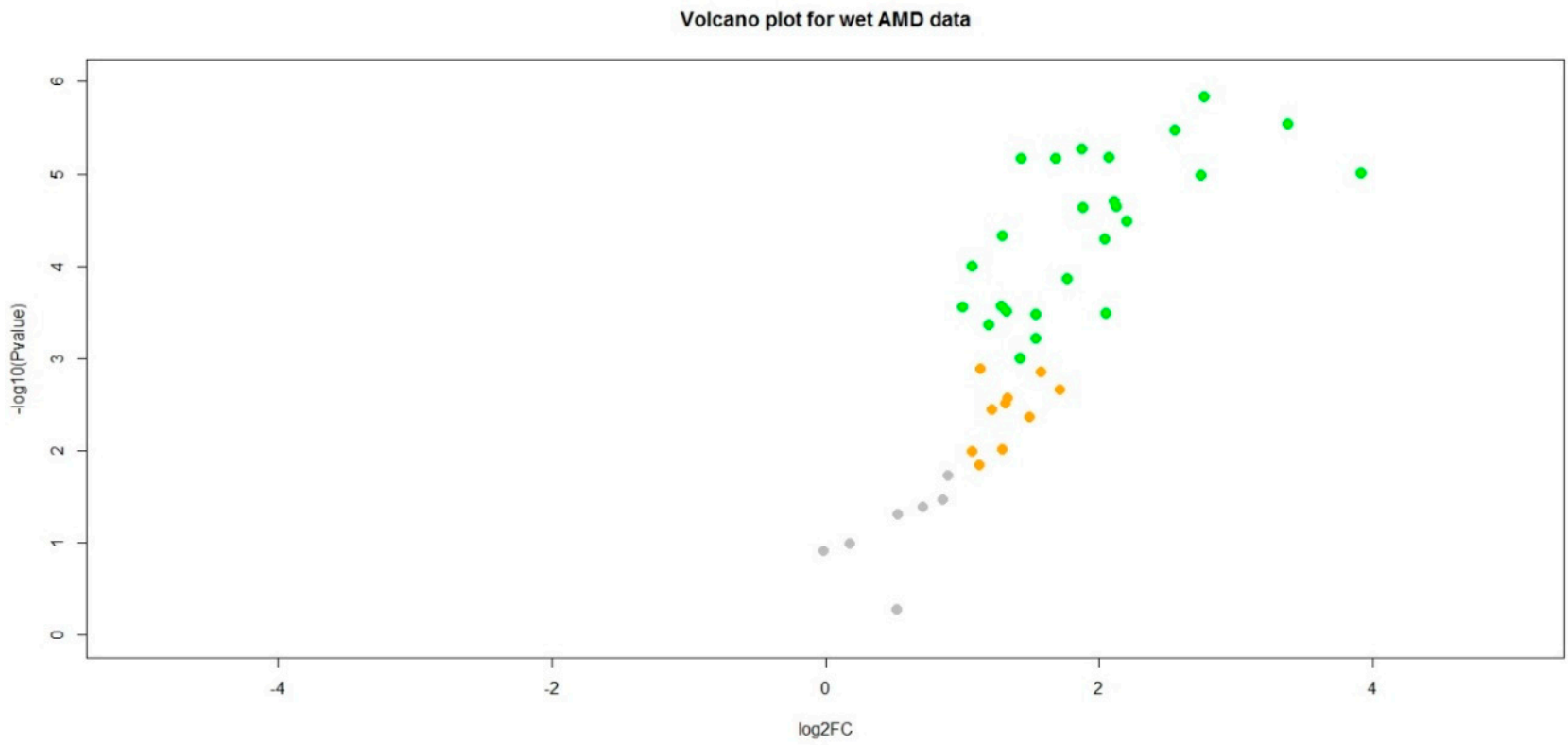

(b)

Figure 4. Volcano plots to show miRNA changes in (a) patients with 'dry' AMD and (b) patients with 'wet' AMD. Points are grey if there is neither a noticeable fold change in gene production nor a difference in gene expression between the control group and the AMD groups, after adjusting for multiple tests. Points are orange if there is a noticeable fold change in gene production, but no difference in gene expression between the control group and the AMD groups, after adjusting for multiple tests. Points are green if there is a noticeable fold change in gene production and a difference in gene expression between the control group and the AMD groups, after adjusting for multiple tests. 


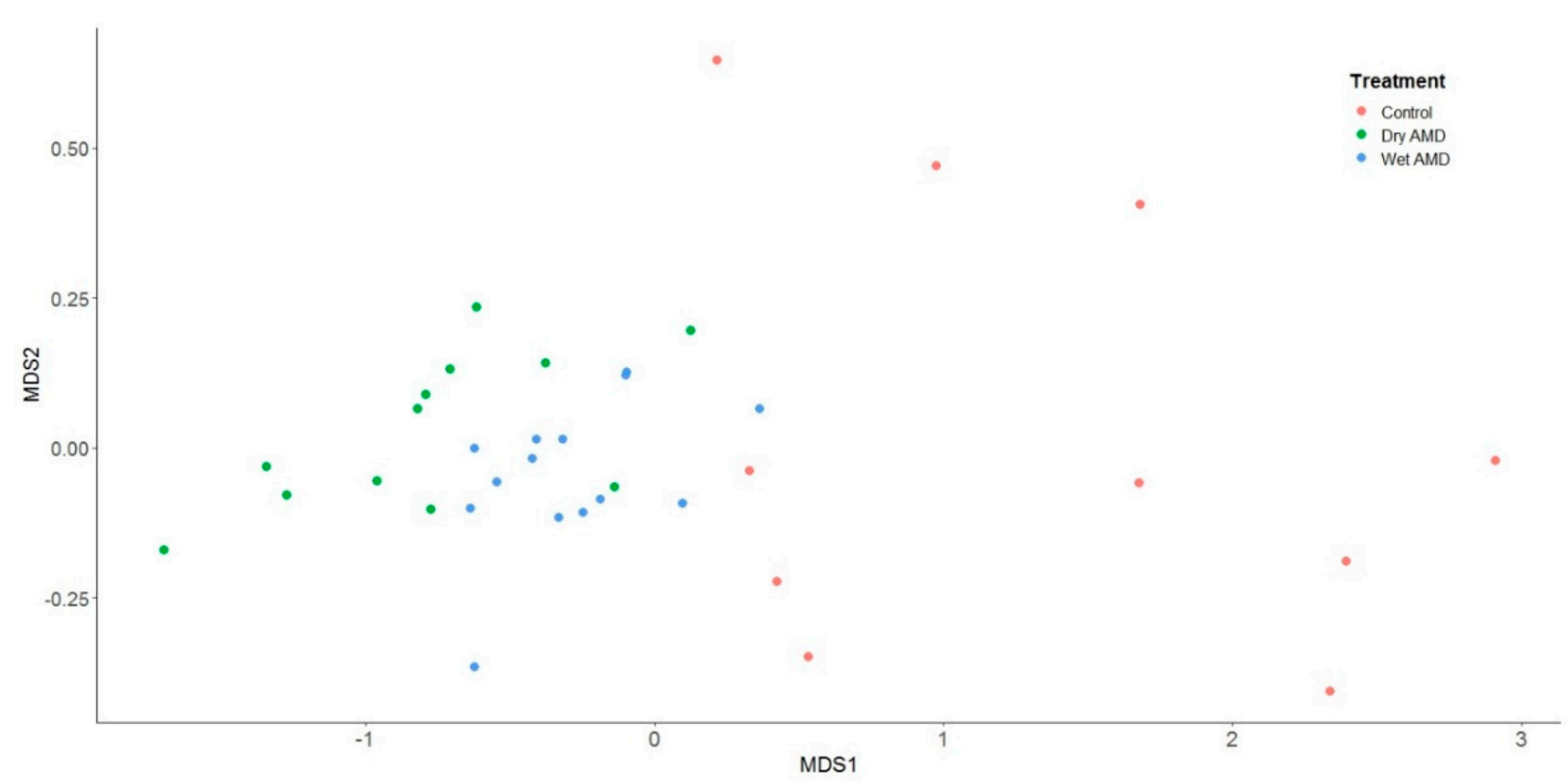

Figure 5. A multidimensional scaling plot of RQ values for each of the miRNAs under investigation from control patients (orange circles), patients with 'dry' AMD (green circles), and patients with 'wet' AMD (blue circles). Patients with both 'dry' and 'wet' AMD provided consistently lower values on the MDS1 axis (equivalent to upregulation of miRNAs). An analysis of variance for the distance matrix (performed by the adonis function within the vegan package in R) demonstrated a significant difference between patient groups $(\mathrm{F}(2,33)=12.462, p<0.01)$.

miRNAs are known to modulate several inflammatory processes, key in the pathogenesis of AMD, and a number of the miRNAs identified in this study have been explored as inflammatory mediators. miR23a-3p, for example, was shown to play a significant role in the modulation of pro-inflammatory TNF- $\alpha$, IL-1 $\beta$, IL-2, IL-4, IL-6, IL-12, and GM-CSF cytokines [14]. In addition to this, miR-19 family members, including miR-19a and miR19b-1, were demonstrated to have a regulatory influence on inflammatory cells in lung cancer models. They accomplish this by modifying the expression of IFN-induced genes and MHC class I genes in human cancer cell lines [47]. Furthermore, miR-19b-1 suppresses the NF-B regulators A20/Tnfaip3, Rnf11, Fbx111/Kdm2a, and Zbtb16, which promotes NF-B activity, a key promoter of inflammation [48].

Prior investigation into the role of circulating miRNAs in AMD by ElShelmani et al., 2021, explored the function of a miR-19a, miR-126, and miR-410 in vitro [49]. This current study found that at least one mature isoform of each of these miRNAs was expressed significantly higher in AMD patients than in healthy controls. The functional analysis of these miRNAs illustrated their roles in regulating VEGF signalling, apoptosis, and neurodegenerative pathways [49].

Interestingly, miR-410-5p and miR-626 did not show any notable difference in expression levels between AMD patients and healthy controls in this study, despite having been validated in AMD patients in previous studies. We hypothesise that these miRNAs might not be useful biomarkers in the context of Irish patients, perhaps because different populations might require different biomarker profiling. Further study would be required to explore and verify this. In contrast to its counterpart, miR-410-3p was significantly elevated in the AMD population. This highlights the diverging function of miRNAs after being processed into their mature forms and their differing functions in pathophysiological processes and warrants further investigation.

Notably, miRNAs shown in this study to be higher in dry AMD than wet AMD were previously shown in this author's previous work to only have been increased in wet AMD [10]. This includes miR-let-7d, miR-27b and miR-874. Though not entirely clear, there may be a number of factors contributing to this discrepancy in results. First, the 
classification of AMD in this patient cohort (dry [non-neovascular] or wet [neovascular]) can be somewhat reductive, and there is ongoing work in clarifying whether or not AMD is really a spectrum of disease or a heterogenous group of disorders [50]. Second, the classification of patients as either dry or wet AMD in this study was conducted at a specific timepoint. Current clinical diagnostic methods fall short of identifying patients who are likely to develop neovascular changes. Further prospective research will be required to identify patients that might convert to wet AMD over time.

One potential limitation of this study is the small amount of miRNA collected from serum samples, meaning miRNAs were tested in single wells rather than in triplicate. This issue was overcome, however, by maximising our yield of good-quality miRNA from samples using the Qiagen extraction purification. Samples were quality controlled using the miRCURY LNA miRNA QC PCR panel, incorporating spike-in sequences to validate the quantity and quality of miRNA extracted.

Healthy volunteers were selected for this study. The study excluded patients and controls with co-existing ocular pathology and/or underlying systemic disorders such as diabetes, high blood pressure, and other inflammatory conditions which affect retinal health and could potentially skew results. Finding such patients in an elderly population proved difficult. Therefore, despite the fact that AMD patients were gender and agematched with controls, there is potential for selection bias in this study. It is unclear whether this affected the variability of miRNA expression in either group.

In conclusion, we successfully validated the biomarker potential of a number of circulating miRNAs and characterised their expression in the context of an Irish population. We specifically focused on the mature miRNAs to better characterise miRNAs previously linked to AMD. The serum miRNAs that were identified show promise as potential serum biomarkers for the development of AMD. Interestingly, some of the miRNAs showed little to no change in expression from control to AMD patients, suggesting that these miRNAs may not be useful in the context of a white Irish population. Further investigation with a larger sample size in a more heterogenous population is needed. Additionally, candidate miRNAs identified should be assessed using prospective longitudinal studies to fully explore their usefulness as early indicators of disease and disease progression.

\section{Materials and Methods}

\subsection{Case-Controlled Study Design}

Clinically documented AMD patients and control blood donors were recruited at the Mater Misericordiae University Hospital (MMUH), Dublin. Ethics approval for the study was obtained from MMUH according to the tenets of the Declaration of Helsinki. All study participants were Caucasians from Ireland. All participants were over 60 years of age. Patients and controls with co-existing ocular pathology and/or underlying systemic diseases such as diabetic retinopathy, high blood pressure, and other inflammatory conditions were excluded from the study. Patients with AMD received a comprehensive eye examination by a clinician (DK) in the MMUH Eye Clinic and provided written informed consent. AMD patients from MMUH were defined and graded using the Age-Related Eye Disease Study (AREDS) macular degeneration classification system [51]. Blood specimens were collected, patient identifiers were removed, and the specimens were encoded to protect donor confidentiality. The study was designed to compare miRNA profiles in a number $(n=36)$ of control samples and dry/wet-AMD serum samples. AMD disease status was categorically based on fundus examination (dry or wet AMD). Study population characteristics are summarised in Table 3. 
Table 3. Patient characteristics $(n=36)$.

\begin{tabular}{ccccc}
\hline \multicolumn{2}{c}{ Characteristic } & Control $(\boldsymbol{n = 1 0 )}$ & Dry $(\boldsymbol{n = 1 2})$ & Wet $(\boldsymbol{n}=\mathbf{1 4})$ \\
\hline \multirow{4}{*}{ Age } & Mean & 72 & 70 & 75 \\
& $60-69$ & $n=2$ & $n=9$ & $n=5$ \\
& $70-79$ & $n=8$ & $n=3$ & $n=8$ \\
Gender & $>80$ & $n=0$ & $n=0$ & $n=1$ \\
& Female & $n=6$ & $n=7$ & $n=9$ \\
& Male & $n=4$ & $n=5$ & $n=5$ \\
\hline
\end{tabular}

\subsection{Human Serum Preparation}

In order to collect serum samples, non-fasting blood specimens were collected with consent from each patient and control. From the collected blood samples, the red blood cells were allowed to clot naturally. These specimens were processed within 3-4 h of blood draw. The tubes were centrifuged at $400 \times g$ for $15 \mathrm{~min}$. Following centrifugation, $1-1.5 \mathrm{~mL}$ of the serum was carefully removed, aliquoted and stored immediately at $-80{ }^{\circ} \mathrm{C}$ until use.

\subsection{RNA Extraction}

Total RNA was extracted using a miRNeasy Serum/Plasma kit (Qiagen, Manchester, UK) according to the manufacturer's protocol. First, $200 \mu \mathrm{L}$ of patient serum was aliquoted into a $2 \mathrm{~mL}$ microcentrifuge tube, to which $60 \mu \mathrm{L}$ of lysis buffer RPL (Qiagen, UK) was added, and $1 \mu \mathrm{L}$ of UniSp2, UniSp4, and UniSp5 RNA spike-in mix was added to the lysis buffer. The tube was mixed vigorously by vortexing for $5 \mathrm{~s}$ and left at room temperature $\left(15-25^{\circ} \mathrm{C}\right)$ for $3 \mathrm{~min}$ to ensure complete lysis. Following this, $3.5 \mu \mathrm{L}$ of miRNeasy Serum/Plasma Spike-In Control (Qiagen, UK) and lysis buffer was added and mixed thoroughly. $20 \mu \mathrm{L}$ of buffer RPP was then added to precipitate the protein inhibitors in the serum. The tube was mixed vigorously by vortexing for $20 \mathrm{~s}$ to ensure precipitation and denaturation of serum proteins. This was left to stand at room temperature for a further $3 \mathrm{~min}$. Tubes were then centrifuged at $12,000 \times g$ for $3 \mathrm{~min}$ using a centrifuge at room temperature to pellet the precipitated serum proteins.

The supernatant, which contains the RNA, was transferred to a fresh microcentrifuge tube and 1 volume of isopropanol was added to the tube. This allowed for suitable binding conditions for RNA molecules $\geq 18$ nucleotides in length. The tube was mixed well by vortexing. The entire sample was then pipetted into a RNeasy UCP MinElute column (Qiagen, UK), within a $2 \mathrm{~mL}$ collection tube. The sample was then centrifuged for $15 \mathrm{~s}$ at $\geq 8000 \times g$. The RNA bound to the matrix in the RNeasy UCP MinElute column. The flow-through in the collection tube was disposed of.

A number of washing steps were then undertaken, using $700 \mu \mathrm{L}$ of Buffer RWT (Qiagen, UK), followed by $500 \mu \mathrm{L}$ of Buffer RPE (Qiagen, UK) and finally $500 \mu \mathrm{L}$ of $80 \%$ ethanol, each time centrifuging the sample and discarding the flow-through. For the wash steps using Buffer RWT and Buffer RPE, the tubes were centrifuged for $15 \mathrm{~s}$ at $\geq 8000 \times g$, with the flow-through discarded. For the ethanol wash step the sample was centrifuged for 2 min at $\geq 8000 \times g(\geq 10,000 \mathrm{rpm})$, again disposing of the flow through.

Particular care was taken in removing the spin column from the collecting tube to ensure that the ethanol did not interfere with downstream reactions. Additionally, several steps were taken to dry the membrane of the RNeasy UCP MinElute spin column. First, the spin column was carefully removed from the collection tube, ensuring that the column did not touch the eluted flow-through containing ethanol. The column was placed into a new $2 \mathrm{~mL}$ collection tube and the membrane of the spin column was then dried by centrifugation at full speed for $5 \mathrm{~min}$, this time with the lid open. Any and all flow-through was then discarded. Finally, to elute the total RNA, the RNeasy UCP MinElute spin column was transferred to a fresh $1.5 \mathrm{~mL}$ collection tube. Then, $20 \mu \mathrm{L}$ of RNase-free water was pipetted directly to the centre of the column membrane and left to stand for $1 \mathrm{~min}$. The 
sample was then centrifuged for $1 \mathrm{~min}$ at full speed, with isolated RNA contained in the flow-through.

\subsection{Quality of Extracted RNA}

The miRCURY LNA miRNA QC PCR Panel was used to analyse the robustness of the RNA isolation process and quality of isolated miRNA. The panel consists of 96-well PCR plates containing dried-down LNA PCR assays for one $10 \mu \mathrm{L}$ real-time PCR reaction per well (Tables S2 and S3). UniSp2, UniSp4 and UniSp5 provide a control for the quality of the RNA isolation in any miRNA quantitative reverse-transcription PCR (qRT-PCR) experiment. miR-103-3p and miR-191-5p are well expressed in most tissues, whereas miR-451a and miR-23a-3p serve as a haemolysis marker and an internal control (Table S3).

Table S2 shows the assays included in the miRCURY LNA miRNA QC PCR Panel. Ahead of isolating the RNA from serum, $1 \mu \mathrm{L}$ of RNA spike-in mix (UniSp2, UniSp4, UniSp5 RNA Spike-in mix, Qiagen, UK) was added to $60 \mu \mathrm{L}$ of lysis buffer RPL. This mixture was added to samples after the addition of lysis buffer RPL but prior to the addition of precipitation buffer RPP, as described in the RNA isolation experiment above. Table S2 shows the application for the quality assay controls. UniSp2, UniSp4, and UniSp5 are present at a 100-fold concentration difference in the RNA Spike-in Kit, which results in approximately 5-7 Rq difference between the spike-ins. $\Delta \mathrm{Rq}$ (miR-23a and miR-451a) lower than 5 in human serum or plasma represents non-haemolyzed samples. If the $\Delta \mathrm{Rq}$ is close to or higher than 7, there is an increased risk of haemolysis.

\subsection{MicroRNA Quantitative Real-Time Polymerase Chain Reaction (qRT-PCR)}

All qRT-PCR reactions were run in a LightCycler ${ }^{\circledR}$ (RT-PCR) 96 instrument (Roche, UK), following the miRCURY LNA miRNA SYBR ${ }^{\circledR}$ Green PCR kit (Qiagen, UK) protocol for exosomes, serum/plasma, and other biofluid samples. The custom serum focus microRNA panel was used for the validation set, which focuses on miRNAs of interest, and includes endogenous controls and RNA spike-in controls. Forty-two selected miRNAs and four endogenous control miRNAs were evaluated from serum in a 96-well plate with all the relevant controls (see Table S2 for the panel assay list).

RNA isolated from serum samples was reverse transcribed to cDNA using the miRCURY LNA RT kit, using a tabletop PCR machine for the 60 -min, $42^{\circ} \mathrm{C}$ incubation required for the reaction, as well as the 5-min-long $95^{\circ} \mathrm{C}$ heat inactivation to terminate it. UniSp6 RNA spike-in controls were added to this reaction to ensure the quality of the experiment. Of the resultant cDNA samples, $5 \mu \mathrm{L}$ was mixed with $195 \mu \mathrm{L}$ of nuclease-free water, achieving a 1:40 dilution of cDNA suitable for the qRT-PCR reaction. The reaction mixture was then prepared by adding $5 \mu \mathrm{L}$ of $2 \times$ miRCURY SYBR ${ }^{\circledR}$ Green Master Mix, $1 \mu \mathrm{L}$ RNase-free water, and $4 \mu \mathrm{L}$ cDNA template. Then, the total $10 \mu \mathrm{L}$ of reaction mixture was dispensed into each of the PCR wells. Following the 2-min initial heat activation of the DNA polymerase enzyme, the PCR reaction was run for a total of 40 cycles. LightCycler ${ }^{\circledR}$ 96 Instrument Software Version 1.2 (Roche, UK) was used to obtain raw $C_{T}$ values. This information was exported (.txt format) for analysis.

\subsection{Quality of $q R T-P C R$}

The quality of the qRT-PCR step was measured again using the miRNeasy Serum/Plasma Spike-In Control (Qiagen, UK). One $\mu$ L UniSp6 of RNA spike-in (Qiagen, UK) was added to samples during the reverse transcription reaction, as described above. RNA spike-in control UniSp6 (CP) was used to evaluate the RT reaction. The expression level of this assay indicated that the reverse transcription was successful; UniSp3 (IPC) evaluated the qPCR reaction which indicated good technical performance of the experiment. 


\subsection{Normalisation}

For the present study, normalisation of serum miRNAs was performed based on the average $C_{T}$ of four normaliser assays, which included miR-323-3p, miR-324-3p, miR-423-3p, and miR-423-5p. miR-323-3p and miR-324-3p were recommended by Applied Biosystems (TLDA manufacturer) and used in previous serum/blood studies as endogenous controls [10]. miR-423-3p and miR-423-5p are stable endogenous candidates that were recommended by the miRNAs custom panel providers (Qiagen, UK [52,53]). The formula used to calculate the normalised values is:

Normalised $C_{T}\left(\mathrm{~d} C_{T}\right)=$ assay $C_{T}$ (sample) - average $C_{T}$ (normaliser assays).

\subsection{Statistical Analyses}

Raw $C_{T}$ data (.txt format) were exported from LightCycler ${ }^{\circledR} 96$ Instrument Software (Roche, UK) and the following formula was used to calculate the fold change in $C_{T}$. Calculations were performed using Excel (Microsoft):

$$
\begin{gathered}
\Delta \mathrm{C}_{\mathrm{T}}=\mathrm{C}_{\mathrm{T}}-\mathrm{C}_{\mathrm{T}} \text { (endogenous control) } \\
\Delta \Delta \mathrm{C}_{\mathrm{T}}=\Delta \mathrm{C}_{\mathrm{T}}-\Delta \mathrm{C}_{\mathrm{T}} \text { control } \\
\text { Fold change (RQ value) }=2-\Delta \Delta \mathrm{C}_{\mathrm{T}}
\end{gathered}
$$

Means and standard deviations were determined. The significance of difference in serum miRNA expression between cohorts (wet AMD, dry AMD, and control) was assessed using analysis of variance (ANOVA) with the Holm-Bonferroni method. In order to evaluate the presence of miRNAs specific to each type of AMD, post-hoc tests to interrogate the pairwise comparisons were used to determine whether there was a significant difference between the two samples: wet AMD vs. control and dry AMD vs. control.

Supplementary Materials: The following are available online at https:/ /www.mdpi.com/article/10 $.3390 /$ ijms222212321/s1.

Author Contributions: Conceptualization, D.K. and H.E.; methodology, H.E.; software, H.E. and D.J.K.; validation, H.E. and I.B.; formal analysis, H.E. and D.J.K.; investigation, H.E.; resources, D.K.; data curation, H.E.; writing-original draft preparation, H.E. and I.B.; writing-review and editing, D.K.; visualization, H.E.; supervision, D.K.; project administration, D.K.; funding acquisition, D.K. All authors have read and agreed to the published version of the manuscript.

Funding: This research was funded by the Mater Vision Institute, Retina Research Group and the HSE Academic Internship Training Program.

Institutional Review Board Statement: The study was conducted according to the guidelines of the Declaration of Helsinki and approved by the Research Ethics Committee (protocol code 1/378/1485), Mater Misericordiae University Hospital, Dublin, Ireland.

Informed Consent Statement: Informed consent was obtained from all subjects involved in the study.

Data Availability Statement: The data is available within the text and the supplementary section. Also, available at Next Generation Sequencing laboratory, Mater Misericordiae University Hospital, Dublin, Ireland.

Conflicts of Interest: The authors declare no conflict of interest. The funders had no role in the design of the study; in the collection, analyses, or interpretation of data; in the writing of the manuscript, or in the decision to publish the results. 


\section{References}

1. Wang, L.; Lee, A.Y.W.; Wigg, J.P.; Peshavariya, H.; Liu, P.; Zhang, H. miRNA involvement in angiogenesis in age-related macular degeneration. J. Physiol. Biochem. 2016, 72, 583-592. [CrossRef]

2. Grassmann, F.; Schoenberger, P.G.A.; Brandl, C.; Schick, T.; Hasler, D.; Meister, G.; Fleckenstein, M.; Lindner, M.; Helbig, H.; Fauser, S.; et al. A Circulating MicroRNA Profile Is Associated with Late-Stage Neovascular Age-Related Macular Degeneration. PLoS ONE 2014, e107461. [CrossRef]

3. Liu, C.H.; Huang, S.; Britton, W.R.; Chen, J. MicroRNAs in vascular eye diseases. Int. J. Mol. Sci. 2020, 21, 649. [CrossRef] [PubMed]

4. Romano, G.L.; Platania, C.B.M.; Drago, F.; Salomone, S.; Ragusa, M.; Barbagallo, C.; Di Pietro, C.; Purrello, M.; Reibaldi, M.; Avitabile, T.; et al. Retinal and circulating miRNAs in age-related macular degeneration: An in vivo animal and human study. Front. Pharmacol. 2017, 8, 168. [CrossRef] [PubMed]

5. Askou, A.L.; Alsing, S.; Holmgaard, A.; Bek, T.; Corydon, T.J. Dissecting microRNA dysregulation in age-related macular degeneration: New targets for eye gene therapy. Acta Ophthalmol. 2018, 96, 9-23. [CrossRef] [PubMed]

6. Berber, P.; Grassmann, F.; Kiel, C.; Weber, B.H.F. An Eye on Age-Related Macular Degeneration: The Role of MicroRNAs in Disease Pathology. Mol. Diagn. Ther. 2017, 21, 31-43. [CrossRef]

7. Blasiak, J.; Watala, C.; Tuuminen, R.; Kivinen, N.; Koskela, A.; Uusitalo-Järvinen, H.; Tuulonen, A.; Winiarczyk, M.; Mackiewicz, J.; Zmorzyński, S.; et al. Expression of VEGFA-regulating miRNAs and mortality in wet AMD. J. Cell Mol. Med. 2019, 23, 8464-8471. [CrossRef]

8. Elbay, A.; Ercan, Ç.; Akbaş, F.; Bulut, H.; Ozdemir, H. Three new circulating microRNAs may be associated with wet age-related macular degeneration. Scand. J. Clin. Lab. Investig. 2019, 79, 388-394. [CrossRef]

9. Ren, C.; Liu, Q.; Wei, Q.; Cai, W.; He, M.; Du, Y.; Xu, D.; Wu, Y.; Yu, J. Circulating miRNAs as Potential Biomarkers of Age-Related Macular Degeneration. Cell. Physiol. Biochem. 2017, 41, 1413-1423. [CrossRef]

10. ElShelmani, H.; Wride, M.A.; Saad, T.; Rani, S.; Kelly, D.J.; Keegan, D. Identification of Novel Serum MicroRNAs in Age-Related Macular Degeneration. Transl. Vis. Sci. Technol. 2020, 9, 28. [CrossRef]

11. Szemraj, M.; Bielecka-Kowalska, A.; Oszajca, K.; Krajewska, M.; Goś, R.; Jurowski, P.; Kowalski, M.; Szemraj, J. Serum micrornas as potential biomarkers of AMD. Med. Sci. Monit. 2015, 21, 2734-2742. [CrossRef] [PubMed]

12. Yao, Q.; Chen, Y.; Zhou, X. The roles of microRNAs in epigenetic regulation. Curr. Opin. Chem. Biol. 2019, 51, 11-17. [CrossRef] [PubMed]

13. Goodall, E.F.; Leach, V.; Wang, C.; Cooper-Knock, J.; Heath, P.R.; Baker, D.; Drew, D.R.; Saffery, M.J.; Simpson, J.E.; Romero, I.A.; et al. Age-associated mRNA and miRNA expression changes in the blood-brain barrier. Int. J. Mol. Sci. 2019, 20, 3097. [CrossRef] [PubMed]

14. Litwińska, Z.; Sobuś, A.; Łuczkowska, K.; Grabowicz, A.; Mozolewska-Piotrowska, K.; Safranow, K.; Kawa, M.P.; Machalinski, B.; Machalińska, A. The Interplay Between Systemic Inflammatory Factors and MicroRNAs in Age-Related Macular Degeneration. Front. Aging Neurosci. 2019, 11, 286. [CrossRef]

15. Wang, S.; Koster, K.M.; He, Y.; Zhou, Q. miRNAs as potential therapeutic targets for age-related macular degeneration. Future Med. Chem. 2012, 281, 5251-5264. [CrossRef]

16. Murad, N.; Kokkinaki, M.; Gunawardena, N.; Gunawan, M.S.; Hathout, Y.; Janczura, K.J.; Theos, A.C.; Golestaneh, N. miR184 regulates ezrin, LAMP-1 expression, affects phagocytosis in human retinal pigment epithelium and is downregulated in age-related macular degeneration. FEBS J. 2014, 281, 5251-5264. [CrossRef]

17. Strafella, C.; Errichiello, V.; Caputo, V.; Aloe, G.; Ricci, F.; Cusumano, A.; Novelli, G.; Giardina, E.; Cascella, R. The Interplay between miRNA-Related Variants and Age-Related Macular Degeneration: EVIDENCE of Association of MIR146A and MIR27A. Int. J. Mol. Sci. 2019, 20, 1578. [CrossRef] [PubMed]

18. Su, Y.; Yi, Y.; Li, L.; Chen, C. circRNA-miRNA-mRNA network in age-related macular degeneration: From construction to identification. Exp. Eye Res. 2021, 203, 108427. [CrossRef] [PubMed]

19. Glinge, C.; Clauss, S.; Boddum, K.; Jabbari, R.; Jabbari, J.; Risgaard, B.; Tomsits, P.; Hildebrand, B.; Kääb, S.; Wakili, R.; et al. Stability of Circulating Blood-Based MicroRNAs-Pre-Analytic Methodological Considerations. PLoS ONE 2017, 12, e0167969. [CrossRef]

20. Natoli, R.; Fernando, N. MicroRNA as therapeutics for age-related macular degeneration. In Advances in Experimental Medicine and Biology; Springer: New York, NY, USA, 2018; pp. 37-43.

21. Ertekin, S.; Yildirim, Ö.; Dinç, E.; Ayaz, L.; Balci Fidanci, Ş.; Tamer, L. Evaluation of circulating miRNAs in wet age-related macular degeneration. Mol. Vis. 2014, 20, 1057-1066.

22. Bian, H.; Zhou, Y.; Zhou, D.; Zhang, Y.; Shang, D.; Qi, J. The latest progress on miR-374 and its functional implications in physiological and pathological processes. Cell. Mol. Med. 2019, 23, 3063-3076. [CrossRef]

23. Nunes, D.N.; Dias-Neto, E.; Cardó-Vila, M.; Edwards, J.K.; Dobroff, A.S.; Giordano, R.J.; Mandelin, J.; Brentani, H.; Hasselgren, C.; Yao, V.J.; et al. Synchronous down-modulation of miR-17 family members is an early causative event in the retinal angiogenic switch. Proc. Natl. Acad. Sci. USA 2015, 112, 3770-3775. [CrossRef] 
24. Ulańczyk, Z.; Sobuś, A.; Łuczkowska, K.; Grabowicz, A.; Mozolewska-Piotrowska, K.; Safranow, K.; Kawa, M.P.; Pałucha, A.; Krawczyk, M.; Sikora, P.; et al. Associations of microRNAs, angiogenesis-regulating factors and CFH Y402H polymorphism-an attempt to search for systemic biomarkers in age-related macular degeneration. Int. J. Mol. Sci. 2019, 20, 5750. [CrossRef] [PubMed]

25. Pogue, A.I.; Lukiw, W.J. Up-regulated Pro-inflammatory MicroRNAs (miRNAs) in Alzheimer's disease (AD) and Age-Related Macular Degeneration (AMD). Cell. Mol. Neurobiol. 2018, 38, 1021-1031. [CrossRef] [PubMed]

26. Zhou, Q.; Gallagher, R.; Ufret-Vincenty, R.; Li, X.; Olson, E.N.; Wang, S. Regulation of angiogenesis and choroidal neovascularization by members of microRNA-23 27 24 clusters. Proc. Natl. Acad. Sci. USA 2011, 108, 8287-8292. [CrossRef] [PubMed]

27. Hou, Q.; Tang, J.; Wang, Z.; Wang, C.; Chen, X.; Hou, L.; Da Dong, X.; Tu, L. Inhibitory effect of microRNA-34a on retinal pigment epithelial cell proliferation and migration. Investig. Ophthalmol. Vis. Sci. 2013, 54, 6481-6488. [CrossRef]

28. Smit-McBride, Z.; Forward, K.I.; Nguyen, A.T.; Bordbari, M.H.; Oltjen, S.L.; Hjelmeland, L.M. Age-dependent increase in miRNA-34a expression in the posterior pole of the mouse eye. Mol. Vis. 2014, 20, 1569-1578.

29. Moreno-García, L.; López-Royo, T.; Calvo, A.C.; Toivonen, J.M.; de la Torre, M.; Moreno-Martínez, L.; Molina, N.; Aparicio, P.; Zaragoza, P.; Manzano, R.; et al. Competing endogenous rna networks as biomarkers in neurodegenerative diseases. Int. J. Mol. Sci. 2020, 21, 9582. [CrossRef]

30. Zhang, J.; Wang, J.; Zheng, L.; Wang, M.; Lu, Y.; Li, Z.; Lian, C.; Mao, S.; Hou, X.; Li, S.; et al. miR-25 Mediates Retinal Degeneration Via Inhibiting ITGAV and PEDF in Rat. Curr. Mol. Med. 2017, 17, 359-374. [CrossRef]

31. Ménard, C.; Rezende, F.A.; Miloudi, K.; Wilson, A.; Tétreault, N.; Hardy, P.; SanGiovanni, J.P.; De Guire, V.; Sapieha, P. MicroRNA signatures in vitreous humour and plasma of patients with exudative AMD. Oncotarget 2016, 7, 19171-19184. [CrossRef]

32. Bai, S.; Tian, B.; Li, A.; Yao, Q.; Zhang, G.; Li, F. MicroRNA-125b promotes tumor growth and suppresses apoptosis by targeting DRAM2 in retinoblastoma. Eye 2016, 30, 1630-1638. [CrossRef] [PubMed]

33. Murray, A.R.; Chen, Q.; Takahashi, Y.; Zhou, K.K.; Park, K.; Ma, J.X. MicroRNA-200b downregulates oxidation resistance 1 (Oxr1) expression in the retina of type 1 diabetes model. Investig. Ophthalmol. Vis. Sci. 2013, 54, 1689-1697. [CrossRef] [PubMed]

34. McArthur, K.; Feng, B.; Wu, Y.; Chen, S.; Chakrabarti, S. MicroRNA-200b regulates vascular endothelial growth factor-mediated alterations in diabetic retinopathy. Diabetes 2011, 60, 1314-1323. [CrossRef] [PubMed]

35. Oltra, M.; Vidal-Gil, L.; Maisto, R.; Sancho-Pelluz, J.; Barcia, J.M. Oxidative stress-induced angiogenesis is mediated by miR-205-5p. J. Cell. Mol. Med. 2020, 24, 1428-1436. [CrossRef]

36. Tsai, K.W.; Leung, C.M.; Lo, Y.H.; Chen, T.W.; Chan, W.C.; Yu, S.Y.; Tu, Y.-T.; Lam, H.-C.; Li, S.-C.; Ger, L.-P.; et al. Arm Selection Preference of MicroRNA-193a Varies in Breast Cancer. Sci. Rep. 2016, 6, 28176. [CrossRef]

37. Zhang, Y.; Yang, P.; Sun, T.; Li, D.; Xu, X.; Rui, Y.; Li, C.; Chong, M.; Ibrahim, T.; Mercatali, L.; et al. MiR-126 and miR-126 * repress recruitment of mesenchymal stem cells and inflammatory monocytes to inhibit breast cancer metastasis. Nat. Cell. Biol. 2013, 15, 284-294. [CrossRef]

38. Zhang, Z.; Pi, J.; Zou, D.; Wang, X.; Xu, J.; Yu, S.; Zhang, T.; Li, F.; Zhang, X.; Zhao, H.; et al. microRNA arm-imbalance in part from complementary targets mediated decay promotes gastric cancer progression. Nat. Commun. 2019, 10, 1-16. [CrossRef]

39. Kozomara, A.; Birgaoanu, M.; Griffiths-Jones, S. MiRBase: From microRNA sequences to function. Nucleic Acids Res. 2019, 47, D155-D162. [CrossRef]

40. Kozomara, A.; Griffiths-Jones, S. MiRBase: Annotating high confidence microRNAs using deep sequencing data. Nucleic Acids Res. 2014, 42, D68-D73. [CrossRef]

41. Chen, Z.; Lai, T.C.; Jan, Y.H.; Lin, F.M.; Wang, W.C.; Xiao, H.; Wang, Y.-T.; Sun, W.; Cui, X.; Li, Y.-S.; et al. Hypoxia-responsive miRNAs target argonaute 1 to promote angiogenesis. J. Clin. Investig. 2013, 123, 1057-1067. [CrossRef]

42. Lin, H.; Qian, J.; Castillo, A.C.; Long, B.; Keyes, K.T.; Chen, G.; Ye, Y. Effect of miR-23 on Oxidant-induced injury in human retinal pigment epithelial cells. Investig. Ophthalmol. Vis. Sci. 2011, 52, 6308-6314. [CrossRef]

43. Jiang, D.; Sun, X.; Wang, S.; Man, H. Upregulation of miR-874-3p decreases cerebral ischemia/reperfusion injury by directly targeting BMF and BCL2L13. Biomed. Pharmacother. 2019, 117, 108941. [CrossRef] [PubMed]

44. Kumar, P.; Dezso, Z.; MacKenzie, C.; Oestreicher, J.; Agoulnik, S.; Byrne, M.; Bernier, F.; Yanagimachi, M.; Aoshima, K.; Oda, Y. Circulating miRNA Biomarkers for Alzheimer's Disease. Hill AF, editor. PLoS ONE 2013, 8, e69807. [CrossRef] [PubMed]

45. Shahriari, F.; Satarian, L.; Moradi, S.; Zarchi, A.S.; Günther, S.; Kamal, A.; Totonchi, M.; Mowla, S.; Braun, T.; Baharvand, H. MicroRNA profiling reveals important functions of miR-125b and let-7a during human retinal pigment epithelial cell differentiation. Exp. Eye Res. 2020, 190, 107883. [CrossRef]

46. Zhao, J.; Li, H.; Chang, N. LncRNA hotair promotes MPP+-induced neuronal injury in Parkinson's disease by regulating the miR-874-5p/ATG10 axis. EXCLI J. 2020, 19, 1141-1153. [PubMed]

47. Li, J.; Lin, T.Y.; Chen, L.; Liu, Y.; Dian, M.J.; Hao, W.C.; Lin, X.L.; Li, X.Y.; Li, Y.L.; Lian, M.; et al. Mir-19 regulates the expression of interferon-induced genes and mhc class i genes in human cancer cells. Int. J. Med. Sci. 2020, 17, 953-964. [CrossRef]

48. Gantier, M.P.; Stunden, H.J.; McCoy, C.E.; Behlke, M.A.; Wang, D.; Kaparakis-Liaskos, M.; Sarvestani, S.T.; Yang, Y.H.; Xu, D.; Corr, S.C.; et al. A miR-19 regulon that controls NF-kB signaling. Nucleic Acids Res. 2012, 40, 8048-8058. [CrossRef] [PubMed]

49. ElShelmani, H.; Wride, M.A.; Saad, T.; Rani, S.; Kelly, D.J.; Keegan, D. The Role of Deregulated MicroRNAs in Age-Related Macular Degeneration Pathology. Transl. Vis. Sci. Technol. 2021, 10, 12. [CrossRef] 
50. Klein, R.; Meuer, S.M.; Myers, C.E.; Buitendijk, G.H.S.; Rochtchina, E.; Choudhury, F.; De Jong, P.T.V.M.; McKean-Cowdin, R.; Iyengar, S.; Gao, X.; et al. Harmonizing the Classification of Age-related Macular Degeneration in the Three Continent AMD Consortium. Ophthalmic Epidemiol. 2014, 21, 14. [CrossRef]

51. Group TA-REDSR. The Age-Related Eye Disease Study (AREDS): Design Implications AREDS Report No. 1. Control. Clin. Trials 1999, 20, 573. [CrossRef]

52. Cirillo, P.D.R.; Margiotti, K.; Fabiani, M.; Barros-Filho, M.C.; Sparacino, D.; Cima, A.; Longo, S.A.; Cupellaro, M.; Mesoraca, A.; Giorlandino, C. Multi-analytical test based on serum miRNAs and proteins quantification for ovarian cancer early detection. PLoS ONE 2021, 16, e0255804. [CrossRef] [PubMed]

53. Donati, S.; Ciuffi, S.; Brandi, M.L. Human Circulating miRNAs Real-time qRT-PCR-based Analysis: An Overview of Endogenous Reference Genes Used for Data Normalization. Int. J. Mol. Sci. 2019, 20, 4353. [CrossRef] [PubMed] 